\title{
Soil apparent electrical conductivity and must carbon isotope ratio provide indication of plant water status in wine grape vineyards
}

\author{
Runze Yu ${ }^{1}$ D $\cdot$ Daniele Zaccaria $^{2}$ (D) . Isaya Kisekka ${ }^{2}$ (D) S. Kaan Kurtural ${ }^{1}$ (D)
}

Accepted: 6 January 2021 / Published online: 4 February 2021

(c) The Author(s) 2021

\begin{abstract}
Proximal sensing is being integrated into vineyard management as it provides rapid assessments of spatial variability of soils' and plants' features. The electromagnetic induction (EMI) technology is used to measure soil apparent electrical conductivity $\left(\mathrm{EC}_{\mathrm{a}}\right)$ with proximal sensing and enables to appraise soil characteristics and their possible effects on plant physiological responses. This study was conducted in a micro irrigated Cabernet Sauvignon (Vitis vinifera L.) vineyard to investigate the technical feasibility of appraising plant water status and its spatial variability using soil $\mathrm{EC}_{\mathrm{a}}$ and must carbon isotope ratio analysis $\left(\delta^{13} \mathrm{C}\right)$. Soil temperature and soil water content were monitored in-situ using time domain reflectometry (TDR) sensors. Soil $\mathrm{EC}_{\mathrm{a}}$ was measured with $\mathrm{EMI}$ at two depths [0-1.5 m (deep $\mathrm{EC}_{\mathrm{a}}$ ) and 0-0.75 $\mathrm{m}$ (shallow $\mathrm{EC}_{\mathrm{a}}$ )] over the course of the crop season to capture the temporal dynamics and changes. At the study site, the main physical and chemical soil characteristics, i.e. soil texture, gravel, pore water electrical conductivity $\left(\mathrm{EC}_{\mathrm{e}}\right)$, organic carbon, and soil water content at field capacity, were determined from samples collected auguring the soil at equidistant points that were identified using a regular grid. Midday stem water potential $\left(\Psi_{\text {stem }}\right)$ and leaf gas exchange, including stomatal conductance $\left(g_{\mathrm{s}}\right)$, net carbon assimilation $\left(A_{\mathrm{n}}\right)$, and intrinsic water use efficiency $\left(\mathrm{WUE}_{\mathrm{i}}\right)$ were measured periodically in the vineyard. The $\delta^{13} \mathrm{C}$ of produced musts was measured at harvest. The results indicated that soil water content (relative importance $=24 \%$ ) and texture (silt: relative importance $=22.4 \%$ and clay: relative importance $=18.2 \%$ ) were contributing the most towards soil $\mathrm{EC}_{\mathrm{a}}$. Deep soil $\mathrm{EC}_{\mathrm{a}}$ was directly related to $\Psi_{\text {stem }}\left(\mathrm{r}^{2}=0.7214\right)$ and $g_{\mathrm{s}}\left(\mathrm{r}^{2}=0.5007\right)$. Likewise, $\delta^{13} \mathrm{C}$ of must was directly related to $\Psi_{\text {stem }}\left(\mathrm{r}^{2}=0.9127\right), g_{\mathrm{s}}$ $\left(\mathrm{r}^{2}=0.6985\right)$, and $A_{\mathrm{n}}\left(\mathrm{r}^{2}=0.5693\right)$. Results from this work provided relevant information on the possibility of using spatial soil $\mathrm{EC}_{\mathrm{a}}$ sensing and $\delta^{13} \mathrm{C}$ analysis to infer plant water status and leaf gas exchange in micro irrigated vineyards.
\end{abstract}

Keywords Precision viticulture $\cdot$ Soil-plant-water relations $\cdot$ Apparent soil electrical conductivity $\cdot$ Electromagnetic induction $\cdot$ Proximal sensing $\cdot$ Grapevine

S. Kaan Kurtural

skkurtural@ucdavis.edu

Extended author information available on the last page of the article 


\section{Introduction}

Electromagnetic induction (EMI) for soil sensing has been increasingly studied and used in viticulture systems with the surge of precision agriculture technologies owing to its nondestructive and prompt manner in acquiring soil data in commercial vineyards (Morari et al. 2009; André et al. 2012; Rossi et al. 2013; Yu and Kurtural 2020). Soil apparent electrical conductivity $\left(\mathrm{EC}_{\mathrm{a}}\right)$, or its reciprocal soil apparent electrical resistivity $\left(\mathrm{ER}_{\mathrm{a}}\right)$, is the main variable EMI sensors can measure and is utilized as an integrated variable to assess soil physical and chemical properties, including soil texture, water content, and salinity (Bittelli 2011; Brillante et al. 2014; De Clercq et al. 2009). Other soil characteristics, such as soil compaction and soil clay content can be appraised through soil $\mathrm{EC}_{\mathrm{a}}$ sensing, according to studies conducted by various authors (Hedley et al. 2004; Rodríguez-Pérez et al. 2011; Zarrouk et al. 2012). Previous research work indicated that, depending on the soil types, the severity of water deficits, and the grapevine cultivars, most of the active root zones are frequently distributed within the upper 1.0-1.2 $\mathrm{m}$ soil depth in drip irrigated vineyards (Smart et al. 2006; Soar and Loveys 2007; Steenwerth et al. 2008). Thus, the relationship between soil $\mathrm{EC}_{\mathrm{a}}$ and plant available water can be evaluated through the use of EMI sensors.

In the irrigated vineyards of northern California, when the soil-water salinity is low, the soil moisture content may become one of the main factors influencing soil $\mathrm{EC}_{\mathrm{a}}$ (Brillante et al. 2015). Among many plant physiological variables, plant water status is one of the most critical factors regulating plant physiological processes and responses to environmental parameters (Ojeda et al. 2001; Acevedo-Opazo et al. 2010). The plant water status is commonly assessed by measuring the hydrostatic pressure in plant tissues with a pressure chamber through leaf or stem water potential measurements (Scholander et al. 1965). The processes is time-consuming and labor-intensive, hence it is not practically applicable at field scale in large commercial vineyards. With the possibility to promptly assess soil $\mathrm{EC}_{\mathrm{a}}$ at field scale, EMI sensing eases the burden to identify the variability in soil and, potentially, the plant response in terms of plant water status and berry development (Bramley et al. 2011a; Tagarakis et al. 2013). Although the soil water content can be difficult to quantitatively predict from soil $\mathrm{EC}_{\mathrm{a}}$ assessments, due to the heterogeneity of vineyard soils (Brillante et al. 2014), the soil-plant water continuum can be well explained once the physical and chemical properties are surveyed to make soil $\mathrm{EC}_{\mathrm{a}}$ by proximal sensing explicitly interpretable (Morari et al. 2009). In viticulture research, the performance of grapevines is always the focus of both scientific research and commercial production. With soil texture playing an extremely critical role in grapevine growth and berry development, by providing nutrients and water, proximal soil sensing has the potential to capture the main sources of variability in the vineyards. A few recent studies have investigated how soil $\mathrm{EC}_{\mathrm{a}}$ sensing can be integrated into vineyard management (Brillante et al. 2015; Bonfante et al. 2015; Yu and Kurtural 2020). However, in the recent applications of proximal soil sensing in wine grape vineyards, the functional relationships between the soil $\mathrm{EC}_{\mathrm{a}}$ and the whole plant physiology are lacking thorough investigation and quantification.

Other than soil $\mathrm{EC}_{\mathrm{a}}$ sensing, an integrator of plant water status was recently investigated by analyzing the carbon isotope ratio of must sugars (van Leeuwen et al. 2010; Brillante et al. 2018). Briefly, ribulose 1,5-diphosphate will deplete more of the heavier carbon isotope ${ }^{13} \mathrm{C}$ when stomata close under water deficits in most of the $\mathrm{C} 3$ plants, causing the ${ }^{13} \mathrm{C}-{ }^{12} \mathrm{C}$ ratio to increase (Farquhar et al. 1982, 1989). As a result, the assimilated sucrose in leaves will be translocated into berries and converted to glucose 
and fructose (Dai et al. 2013). The ratio of ${ }^{13} \mathrm{C}$ to ${ }^{12} \mathrm{C}$ was shown to be indirectly related to plant water status and stomatal conductance and net carbon assimilation by earlier studies (Farquhar et al. 1989; Bchir et al. 2016). Based on this mechanism, carbon isotope ratio analysis $\left(\delta^{13} \mathrm{C}\right)$ on berry must sugars can be exploited as an integrated proxy for spatially assessing plant water deficits (Gaudillère et al. 2002). Being able to reveal the accumulated effects of water deficits between veraison and ripening (Bchir et al. 2016), this method can act as a complementary approach to validate proximal soil sensing, without the demand to tracking plant water status throughout the berry maturation, to direct site-specific management for the upcoming season.

Overall, this study aimed at understanding how feasible it was to assess the vine water status through soil $\mathrm{EC}_{\mathrm{a}}$ sensing in wine grape vineyards. This study was also aimed to confirm the hypothesis that water could be the most contributing factors on soil $\mathrm{EC}_{\mathrm{a}}$ in wine grape vineyards. Finally, the possibility of using the must $\delta^{13} \mathrm{C}$ analysis to understand the relationships among grape berry sugar content, plant water status, and leaf photosynthesis would be evaluated. Such relationships may allow using $\delta^{13} \mathrm{C}$, among other variables, for managing vineyard variability in Mediterranean climates.

\section{Materials and methods}

\section{Vineyard site and weather information}

This study was conducted in 2019 in Oakville, California, USA, with Vitis vinifera L. cv. Cabernet Sauvignon grafted on 3309C (V. riparia $\times$ V. rupestris). The grapevines were spaced at $1.5 \mathrm{~m} \times 2.0 \mathrm{~m}$ (vine $\times$ row) and trained as a bi-lateral cordon on a single wire at the height of $1.80 \mathrm{~m}$ above the ground. The grapevines were mechanically pruned to a spur height of $0.10 \mathrm{~m}$ and treated with mechanical shoot removal at Eichhorn-Lorenz (E-L) stage 17 (Coombe 1995) to meet production demands. Bud break occurred on 7 April, 2019 at the study vineyard. The vineyard was drip irrigated with two emitters per plant with a nominal flow rate of $4 \mathrm{~L} \mathrm{~h}^{-1}$. Irrigation events were scheduled from fruit-set to harvest to refill about $50 \%$ of the potential crop evapotranspiration. About $138.6 \mathrm{~mm}$ of irrigation water was applied from fruit set to harvest, which occurred on 20 September 2019. Weather information at the study site was obtained from the automated weather station No. 77 (Oakville, CA) of the California Irrigation Management Information System (CIMIS), which is located about $200 \mathrm{~m}$ away from the study vineyard. The amount of irrigation water to apply was calculated multiplying the reference evapotranspiration $\left(\mathrm{ET}_{\mathrm{o}}\right.$ ), obtained from the local CIMIS station, by an empirical crop adjustment coefficient (Kc) estimated on the basis of the ground shaded area by the vines according to the methodology reported by Williams and Ayars (2005). The growing degree days (GDD) were calculated based on the average air temperature determined from the local CIMIS weather station as:

$$
\mathrm{GDD}=\left[\frac{(\operatorname{Max} T-\operatorname{Min} T)}{2}\right]-\operatorname{Tref}
$$

where Max $\mathrm{T}$ is daily maximum air temperature, Min $\mathrm{T}$ is the minimum air temperature, and $\mathrm{T}_{\text {ref }}$ is the reference temperature of $10{ }^{\circ} \mathrm{C}$. 


\section{Experimental design}

A regular $30 \mathrm{~m} \times 30 \mathrm{~m}$ grid was used to set equidistant points throughout the vineyard with the size of approximately 0.5 ha where field measurements were collected. The grid allowed to identify 14 experimental units that included 3 grapevines per unit. The geolocations of the center grapevine within each experimental unit were registered with a GPS device (Yuma 2, Trimble Inc., Sunnyvale, CA, USA) connected to a Trimble Pro 6 T DGNSS receiver (Trimble Inc., Sunnyvale, CA, USA) to assist further GIS analysis (Fig. 1).

\section{Vineyard soil physical-chemical characteristics}

Soil samples were taken on 29 May 2019, 52 days after bud break (DAB), from two depths in the 14 experimental units, including deep soil $(0.75-1.5 \mathrm{~m})$ and shallow soil $(0-0.75 \mathrm{~m})$. Soil $\mathrm{pH}$, cation exchange capacity (CEC), soil organic carbon (SOC), total nitrogen (TN), and soil texture were measured according to the soil analysis methods of the North American Proficiency Testing (NAPT) program, western states section. Soil $\mathrm{pH}$ was measured with the saturation paste method $(\mathrm{S}-1.10)$, CEC was calculated from the extractable cations measured by ammonium acetate method (S-5.10), SOC and TN were measured by combustion method (S-9.30), soil texture was acquired by hydrometer analysis ( $\mathrm{S}-14.10)$. Soil moisture content, gravel content were determined by the method in Sect. 26 in USDA Handbook No. 60 (Diagnosis and Improvement of Saline and Alkali Soils).

\section{Assessment of spatial and temporal variations of soil features}

Soil $\mathrm{EC}_{\mathrm{a}}$ was measured with an EM38 portable device (Geonics Ltd., Mississauga, ON, Canada), using both the vertical dipole mode (VDM) and horizontal dipole mode (HDM)

A

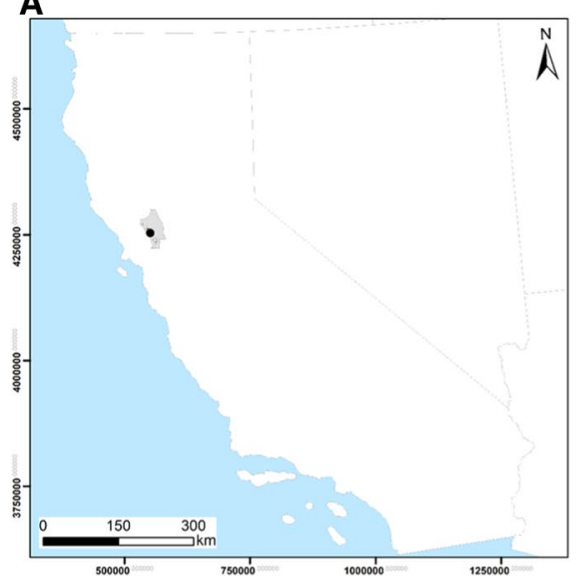

B

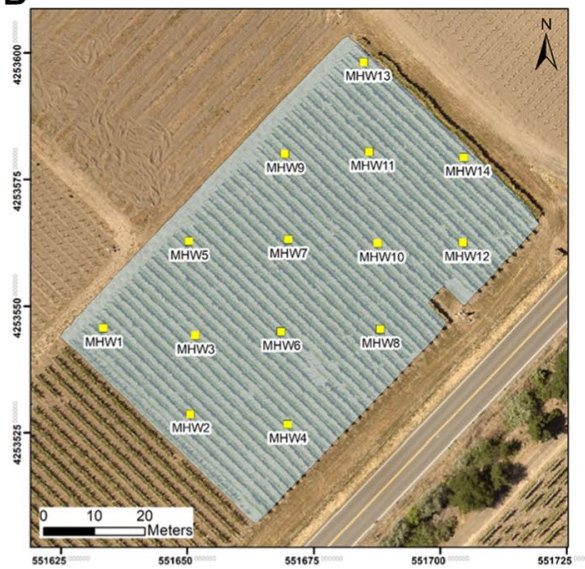

Fig. 1 Location of the experiment site in Oakville, California, USA. a Highlighted area indicates the vineyard location in California, U.S.A. b Map of the experimental block with 14 experimental units marked, yellow squares illustrate the locations of each experimental unit. $M H W$ mechanical high wire. (Fig. 1b previously appeared in Yu and Kurtural 2020) (Color figure online) 
to obtain $\mathrm{EC}_{\mathrm{a}}$ at two depths, i.e. $0-0.75 \mathrm{~m}$ and $0-1.50 \mathrm{~m}$ for shallow and deep soil layers, respectively. The EM38 device was calibrated prior to each soil survey following the manufacturer's instructions in order to minimize errors. The instrument was placed on a sled consisting of PVC frame and was pulled by an all-terrain vehicle along the inter-rows at a distance of about $0.5 \mathrm{~m}$ from the vines to minimize interference phenomena due to metal wires of the trellis system, and about $0.15 \mathrm{~m}$ above the soil surface. The soil $\mathrm{EC}_{\mathrm{a}}$ was first assessed when the vineyard was around field capacity, i.e. $52 \mathrm{DAB}$. Three more measurements were taken on 94, 129, and 166 DAB using the same EM38 mobile device and settings.

Time domain reflectometry (TDR) sensors were installed at four of the 14 experimental units, including MHW1, MHW4, MHW9, and MHW12, which were selected on the basis of two main plant water status zones that were previously determined across the study orchard within a parallel research work (Yu and Kurtural 2020). Each soil moisture measurement location was equipped with an access tube, TDR sensors for in-situ determination of soil water content and with soil pore water electrical conductivity $\left(\mathrm{EC}_{\mathrm{e}}\right)$ meter to assess the soil-water salinity. The soil at the study site corresponds to the Bale soil series and is classified as fine-loamy, mixed, superactive, thermic Cumulic Ultic Haploxerolls according to the USDA soil classification system. The Bale soil series consists of very deep, somewhat poorly drained soils formed in stratified, gravelly and sandy alluvium from mixed sources. In these soil series, Ap horizon is distributed from 0 to $0.15 \mathrm{~m}$ deep, B horizon distributed from 0.15 to $0.61 \mathrm{~m}$, Ab horizon is distributed from 0.61 to $1.12 \mathrm{~m}$, and $\mathrm{C}$ horizon is distributed from 1.12 to $1.47 \mathrm{~m}$. Three TDR sensors (TDR-315, Acclima, Inc., Meridian, ID, USA) were installed at $0.375 \mathrm{~m}, 0.75 \mathrm{~m}$, and $1.45 \mathrm{~m}$ at each location to collect soil measurements for $0-0.75 \mathrm{~m}$ and $0-1.5 \mathrm{~m}$ soil depths by assessing horizons $\mathrm{B}$, $\mathrm{Ab}$, and $\mathrm{C}$. However, the Ap horizon was not monitored by TDR due to the mechanical soil tillage periodically conducted throughout the growing season. The TDR sensors function within \pm 0.1 vol $\%$, for percent soil volumetric water content between 0 and 100 vol $\%$, and $\mathrm{EC}_{\mathrm{e}}$ between 0 and $55 \mathrm{dS} \mathrm{m}^{-1}$. All the soil moisture sensors measured a width of about $0.15 \mathrm{~m}$. As such, the sensors installed at $0.375 \mathrm{~m}$ and $0.75 \mathrm{~m}$ measured the volume corresponding to a depth of $0.75 \mathrm{~m}$ by 0.15 width for shallow soil, whereas the sensors at $0.75 \mathrm{~m}$ and $1.5 \mathrm{~m}$ measured a volume corresponding to a depth of $1.5 \mathrm{~m}$. The values of soil volumetric water content (vol \%) from both the analyses conducted on soil samples and those resulting from the TDR sensors were converted to cumulative soil water content (mm). At each location, the TDR sensors were connected to a DataSnap data logger (SDI12, Acclima, Inc., Meridian, ID, USA) and the measurements were logged automatically every $10 \mathrm{~min}$. The soil moisture data were then averaged at a daily time-step and cleaned following the Tukey rule by removing the outliers whose values were either lower than the first quartile minus 1.5 times the interquartile range (IQR) or higher than third quartile plus 1.5 times the IQR. The soil $\mathrm{EC}_{\mathrm{e}}$, which was continuously monitored by TDR sensors at three depths, was consistently stable throughout the season without considerable increase approaching the harvest. Especially for the sensors at $0.375 \mathrm{~m}$ deep, consistently yielded $\mathrm{EC}_{\mathrm{e}}$ values below 2.5 and $3.0 \mathrm{dS} \mathrm{m}{ }^{-1}$. Hence, it was assumed that the soil at this specific vineyard was non-saline and soil salinity did not act as a temporal fluctuating factor which could dominate $\mathrm{EC}_{\mathrm{a}}$.

Soil $\mathrm{EC}_{\mathrm{a}}$ assessed by EM38 was corrected to a reference temperature of $25^{\circ} \mathrm{C}$ according to Hayashi (Hayashi 2004) with the following equation:

$$
\mathrm{EC}_{25}=E C_{T} /[1+\delta(T-25)]
$$


where $\mathrm{EC}_{25}$ is the $\mathrm{EC}_{\mathrm{a}}$ value at a referenced temperature of $25^{\circ} \mathrm{C}, \mathrm{EC}_{T}$ is the $\mathrm{EC}_{\mathrm{a}}$ value at a measured temperature $T$ by TDR sensors, and $\delta$ is set to $0.0191{ }^{\circ} \mathrm{C}^{-1}$ as the commonly used value based on the $\mathrm{EC}$ and temperature relationship of $0.01 \mathrm{M} \mathrm{KCl}$ solution.

\section{Measurements of grapevine canopy parameters}

Leaf area index (LAI) was measured with a smartphone based program "VitiCanopy" (De Bei et al. 2016) coupled with an iOS system (Apple Inc., Cupertino, CA, United States). The gap fraction threshold was set to 0.75 , the extinction coefficient was set to 0.7 , and sub-divisions were 25 . The device was positioned at about $0.75 \mathrm{~m}$ underneath the canopy, with the maximum length of the screen being perpendicular to the cordon, and the cordon being located at the center of the screen according to the user's instructions.

Normalized differential vegetation index (NDVI) was acquired with Crop Circle ACS430 (Holland Scientific, Lincoln, NE, USA) at canopy closure on 13 May 2020, and calculated as,

$$
\mathrm{NDVI}=(\mathrm{rNIR}-\mathrm{rRED}) \div(\mathrm{rNIR}+\mathrm{rRED})
$$

where rNIR was the reflectance in the near-infrared band, and rRED was the reflectance of the red (visible) band (Kriegler et al. 1969). The measurement was conducted the two sensors mounted on each side of the vineyard vehicle to a height accommodating the trellis. The data was recorded at $1 \mathrm{~Hz}$ to a GeoScout datalogger (Holland Scientific Inc., Lincoln, NE, USA) and geolocated with a Garmin $18 \times 5 \mathrm{~Hz}$ GPS (Garmin Ltd., Olathe, KS, USA).

The spatial homogeneity was tested for LAI and NDVI by Cambardella index (CI), and calculated as,

$$
\mathrm{CI}=\left[\mathrm{c}_{0} /\left(\mathrm{c}_{1}+\mathrm{c}_{0}\right)\right] \times 100
$$

where $\mathrm{c}_{0}$ is the nugget, $\mathrm{c}_{0}+\mathrm{c}_{1}$ is the sill. When CI is less than 25 , there is a strong spatial dependency; between 25 and 75, there is a moderate spatial dependency; more than 75 , there is a weak spatial dependency (Cambardella et al. 1994).

\section{Measurements of plant water status: mid-day stem water potential and leaf gas exchange}

Mid-day stem water potential $\left(\Psi_{\text {stem }}\right)$ measurements were taken bi-weekly over the course of the 2019 growing season. The measurements were taken on 2 July, 17 July, 1 August, 15 August, 29 August, and 20 September in 2019. From the main shoot axes on the grapevines, three shaded leaves were chosen and concealed in pinch-sealed Mylar® bags up to two hours prior to the measurements in each experimental unit. A pressure chamber (Model 615D, PMS Instrument Company, Albany, OR, USA) was used to take the $\Psi_{\text {stem }}$ readings (Williams and Araujo 2002).

On the same dates, leaf gas exchange measurements were also taken at mid-day using a portable infrared gas analyzer CIRAS-3 (PP Systems, Amesbury, MA, USA). Three sun-exposed leaves were chosen from the main shoot axes, and three readings were taken on each selected leaf. In 2019, the sunlight was close to saturating conditions when the leaf gas exchange measurements were taken, where the average $\mathrm{PAR}_{\mathrm{i}}$ was $1749.3 \pm 203.7 \mu \mathrm{mol} \mathrm{m} \mathrm{m}^{-2} \mathrm{~s}^{-1}$. And the average vapor-pressure deficit (VDP) was 
$4.4 \pm 1.7 \mathrm{kPa}$, average leaf temperature was $37.0 \pm 4.2^{\circ} \mathrm{C}$. The standard environmental condition in the infrared gas analyzer was set with a relative humidity at $40 \%$ and a reference $\mathrm{CO}_{2}$ concentration at $400 \mu \mathrm{mol} \mathrm{CO} \mathrm{CO}_{2} \mathrm{~mol}^{-1}$. Net carbon assimilation rate $\left(A_{\mathrm{N}}, \mu \mathrm{mol} \mathrm{CO} 2\right.$ $\left.\mathrm{m}^{-2} \mathrm{~s}^{-1}\right)$ and stomatal conductance $\left(g_{\mathrm{s}}, \mathrm{mmol} \mathrm{H}_{2} \mathrm{O} \mathrm{m}^{-2} \mathrm{~s}^{-1}\right)$ were directly read by the gas analyzer. Intrinsic water use efficiency $\left(\mathrm{WUE}_{\mathrm{i}}, \mu \mathrm{mol} \mathrm{CO}_{2} \mathrm{mmol}^{-1} \mathrm{H}_{2} \mathrm{O}\right.$ ) was calculated as the ratio between $A_{\mathrm{N}}$ and $g_{\mathrm{s}}$, according to equation $\mathrm{WUE}_{\mathrm{i}}=A_{\mathrm{N}} / g_{s}$.

\section{Carbon isotope ratio analysis of berry must sugars $\left(\delta^{13} \mathrm{C}\right)$}

One-hundred berries were randomly collected at harvest from each experimental unit for $\delta^{13} \mathrm{C}$ analysis. The berries were crushed by hand and $1.5 \mathrm{~mL}$ of must was transferred into $2 \mathrm{~mL}$ conical tubes, and centrifuged at 4,000 RPM for $15 \mathrm{~min}$. Afterwards, $10 \mu \mathrm{L}$ of the supernatant from each sample was transferred into tin capsules (Thermo Fisher Scientific, Waltham, MA, USA) and placed in a microplate. The microplates were placed in oven at $80{ }^{\circ} \mathrm{C}$ overnight until completely dehydrated. The open tin capsules were then folded into a cubit, and wrapped, folded with another tin capsule to ensure the seal. The samples were analyzed for isotope ratio on a Vario MicroCube elemental analyzer coupled in a continuous flow mode to an isotope ratio mass spectrometer (IsoPrime, Elementar, Ronkonkoma, NY, USA). The $\delta^{13} \mathrm{C}$ values are reported in parts per thousand (\%o) relative to the Vienna Peedeebelemnite- $\mathrm{CO}_{2}\left(\mathrm{VPDB}-\mathrm{CO}_{2}\right)$ international reference.

\section{Data processing and analysis}

Geostatistical analysis, including kriging for proximal soil sensing, LAI, NDVI and soil characteristics were performed using ArcGIS (version 10.6, Esri, Redlands, CA, USA). The soil and NDVI were filtered by the speed that the vehicle was driving, which was between $3.2 \mathrm{~km}$ per hour and $8.0 \mathrm{~km}$ per hour. The specific soil $\mathrm{EC}_{\mathrm{a}}$ values were extracted from each experimental unit location, and then used for further analysis.

The R software package (R Foundation for Statistical Computing, Vienna, Austria) was used with the 'dplyr' package (Wickham et al. 2020) to perform multivariate regression analysis and derive the model between $\mathrm{EC}_{\mathrm{a}}$ and soil characteristics, including SOC, gravel content, silt content, clay content, soil $\mathrm{EC}_{\mathrm{e}}$, and soil water content. Specifically, a multivariate regression model was developed to allow using the relationships between measured soil characteristics as predictors and $\mathrm{EC}_{\mathrm{a}}$. An analysis of relative importance was performed with 'relaimpo' package (Grömping 2006). Linear regression analysis and graphing were performed using SigmaPlot 13.0 (Systat Software Inc., San Jose, CA, USA). The coefficient of determination between variables was calculated with linear regression analysis, and $p$ values were determined to appraise the significance of the linear fittings, while rootmean-square errors (RMSE) were calculate to evaluate the standard deviation of the unexplained variance.

\section{Results and discussion}

\section{Weather at experiment site}

The experiment site received $10 \%$ of the yearly precipitation during the growing season (Table 1). This amount is typical for the study region and most semi-arid grape production 
Table 1 Weather information at the experiment site as obtained from California Irrigation Management Information System (CIMIS) Station (\#77 Oakville, Napa)

\begin{tabular}{lcllll}
\hline Month-year & $\begin{array}{l}\text { Total precipi- } \\
\text { tation }(\mathrm{mm})\end{array}$ & $\begin{array}{l}\text { Average max air } \\
\text { temperature }\left({ }^{\circ} \mathrm{C}\right)\end{array}$ & $\begin{array}{l}\text { Average min air } \\
\text { temperature }\left({ }^{\circ} \mathrm{C}\right)\end{array}$ & $\begin{array}{l}\text { Average air tem- } \\
\text { perature }\left({ }^{\circ} \mathrm{C}\right)\end{array}$ & $\begin{array}{l}\text { Growing } \\
\text { degree days } \\
\left({ }^{\circ} \mathrm{C}\right)\end{array}$ \\
\hline Oct-18 & 36.3 & 26.4 & 7.2 & 15.8 & - \\
Nov-18 & 135.0 & 21.3 & 3.7 & 11.4 & - \\
Dec-18 & 77.5 & 21.3 & 3.5 & 9 & - \\
Jan-19 & 248.5 & 15.9 & 4.7 & 9.7 & - \\
Feb-19 & 224.3 & 12.9 & 2.7 & 7.5 & - \\
Mar-19 & 145.6 & 17.5 & 4.9 & 11 & 217.6 \\
Apr-19 & 12.5 & 23.3 & 8.8 & 15.4 & 384.35 \\
May-19 & 88.9 & 22.4 & 8.4 & 14.6 & 690.1 \\
Jun-19 & 0.0 & 29.2 & 11.2 & 19.7 & 1016.55 \\
Jul-19 & 0.2 & 29.9 & 11.1 & 19.6 & 1381.05 \\
Aug-19 & 0.0 & 31.2 & 12.3 & 20.8 & 1668.85 \\
Sep-19 & 1.5 & 29.4 & 9.7 & 19.2 & \\
\hline
\end{tabular}

areas. The study site received $970.3 \mathrm{~mm}$ of precipitation from October 2018 to April in 2019, whereas $103.1 \mathrm{~mm}$ of precipitation occurred from April to September in 2019. During the period from June to September in 2019 , only $1.7 \mathrm{~mm}$ of precipitation occurred. The highest air temperatures occurred from June to September in 2019, with an average air temperature of $19.8{ }^{\circ} \mathrm{C}$ and a maximum air temperature of $29.9{ }^{\circ} \mathrm{C}$. The GDD accumulation was calculated from April 1 and reached 1668 at harvest by late September in 2019. According to the Köppen climate classification (Peel et al. 2007), the experiment site was classified as having dry and warm summer climate and noted as 'Csb' and as Region III according to Winkler's index (Winkler et al. 1974).

\section{Spatial distribution of soil physical and chemical properties at experiment site}

For the deep soil layer $(0.75-1.5 \mathrm{~m})$, the percentages of clay and silt were greater in the southwestern section of the vineyard (Fig. 2a, b). Conversely, the percentage of sand was lower in the southwestern section (Fig. 2c). A lower plant water status from this portion of the vineyard was reported in previous research work conducted on the same study site, where, surprisingly, higher clay and silt contents resulted in more water deficits although the plants were irrigated uniformly at $0.5 \mathrm{ET}_{\mathrm{c}}$ (Yu and Kurtural 2020). Although clay and silt are assumed to provide higher water holding capacity and greater soil moisture storage, the results indicated better plant water status in the portion with lower clay and silt contents with deficit irrigation. This was attributed to the fact that water can be more easily taken up by the plants in the sandy soil compared to clay soil when irrigated with water deficit as previously reported (Tramontini et al. 2013). The gravel proportion varied at the experiment site, ranging from $1.65 \%$ to $20.3 \%$ with the central section of vineyard with less gravel (Fig. 2d). The southwestern corner of the vineyard had greater $\mathrm{Ca}^{+}$, but in general there was not a spatial pattern as significant as for the soil texture (Fig. 2e). Soil pH showed lower values in the southeastern and northeastern section and higher values in the rest of the vineyard, ranging from 4.7 to 7.5 (Fig. 2f). There was a similar spatial pattern in CEC as for the soil texture, where 
A

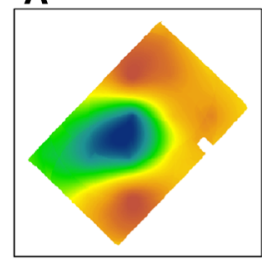

D

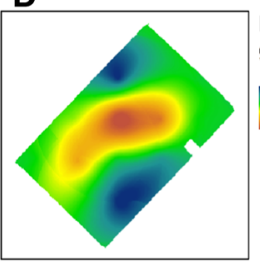

G

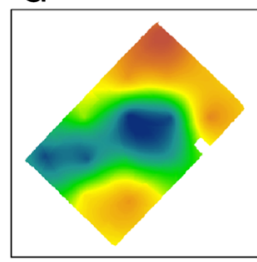

B

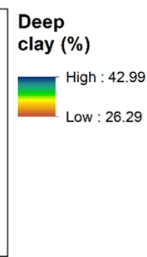

E
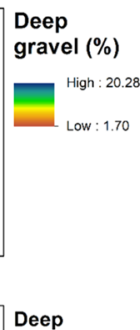

CEC (meq/100g)

High : 36.21 Low : 22.54

H
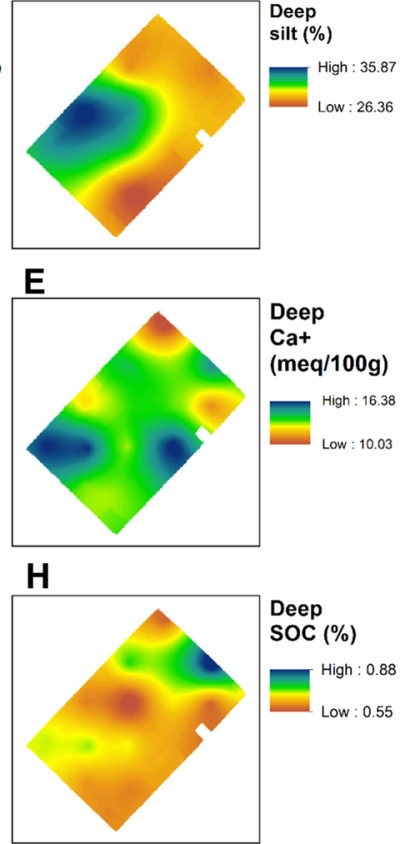

C

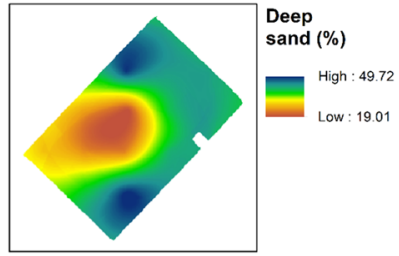

$\mathbf{F}$

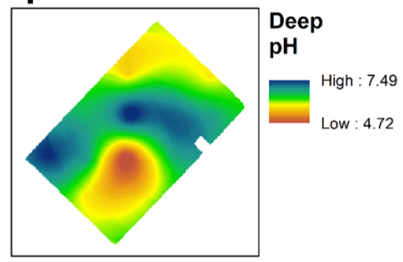

I

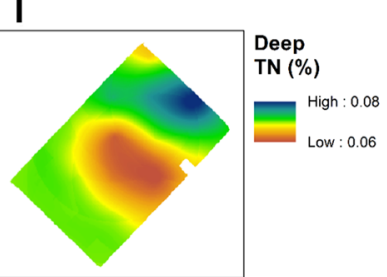

Fig. 2 Soil characteristics for deep depth $(0.75-1.5 \mathrm{~m})$. a Clay in $\%$, b silt in $\%$, $\mathbf{c}$ sand in $\%$, d gravel in $\%$, e $\mathrm{Ca}+$ in millequivalent per $100 \mathrm{~g}$ of soil, $\mathbf{f ~ p H}$, g cation exchange capacity (CEC) in milliequivalent per $100 \mathrm{~g}$ of soil, $\mathbf{h}$ soil organic carbon (SOC) in $\%, \mathbf{i}$ total nitrogen (TN) in \% (Color figure online)

greater CEC was observed in the southwestern section of the vineyard (Fig. 2g). The SOC was relatively uniform except in the northeastern section of the vineyard where slightly higher values were measured (Fig. 2h). Although the central section showed lower TN compared to the rest of the vineyard, as expected, the values were low in the deep soil and the variability was not visible (Fig. $2 \mathrm{i}$ ).

In the shallow soil layer $(0-0.75 \mathrm{~m})$, the soil texture was relatively homogenous compared to that of the deep soil layer. There was only very small area in the northeastern section of the vineyard showing significant difference for clay and sand, where there was higher clay and lower sand compared to the rest of the vineyard. (Fig. 3a, c), while another small portion of the northeastern section showed lower values in silt content (Fig. 3b). Significant variability in the gravel content was observed, where the northeastern section had higher values compared to the rest of the vineyard, from $19.6 \%$ to $9.2 \%$ (Fig. 3d). Soil $\mathrm{Ca}^{+}$showed some variability in the vineyard, where the central section had lower values (Fig. 3e). The $\mathrm{pH}$ was relatively homogenous in the shallow soil layer with little variability ranging from 5.5 to 5.9 (Fig. 3f). The CEC was also homogenous in shallow soil, except for one unit in the southwestern section having 36.7 meq. per $100 \mathrm{~g}$ of soil, which was significantly higher than the rest of the vineyard (Fig. 3g). The soil organic carbon showed a similar pattern as that observed for the deep soil layer, where the northeastern section of the vineyard had higher organic carbon (Fig. 3h). As expected, there was proportionally higher total nitrogen in the shallow soil layer compared to deep soil layer (Fig. 3i). The northwestern corner and northeastern section of the vineyard showed higher nitrogen content. 
A

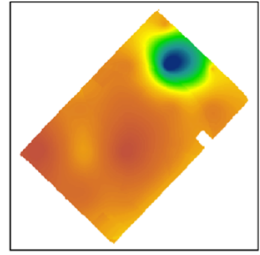

D

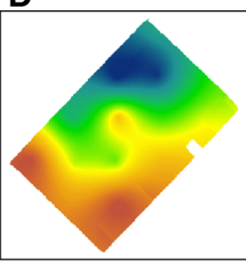

G

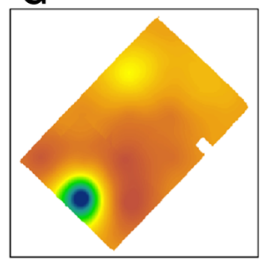

B

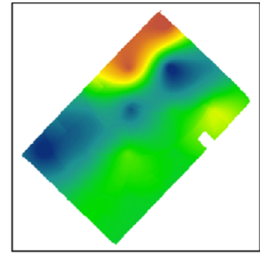

E
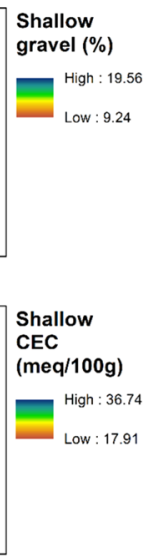

C

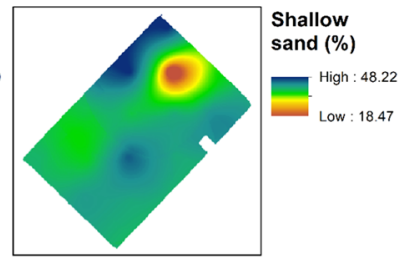

F
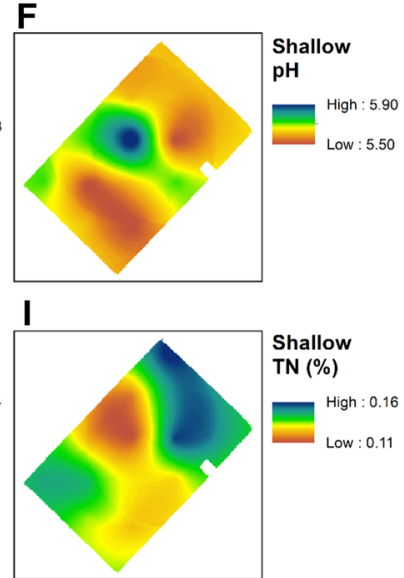

Fig. 3 Soil characteristics for shallow depth $(0-0.75 \mathrm{~m})$. a Clay in $\%$, b silt in $\%$, c sand in $\%$, $\mathbf{d}$ gravel in $\%, \mathbf{e ~} \mathrm{Ca}^{+}$in milliequivalent per $100 \mathrm{~g}$ of soil, $\mathbf{f ~ p H}, \mathbf{g}$ cation exchange capacity (CEC) in milliequivalent per $100 \mathrm{~g}$ of soil, $\mathbf{h}$ soil organic carbon (SOC) in $\%, \mathbf{i}$ total nitrogen (TN) in \% (Color figure online)

\section{Spatial distribution of soil $\mathrm{EC}_{\mathrm{a}}$ across the study vineyard}

The soil $\mathrm{EC}_{\mathrm{a}}$ was periodically measured during the 2019 crop season and showed progressive decreases with time towards the harvest (Fig. 4). For deep soil, 52 days DAB, the

A

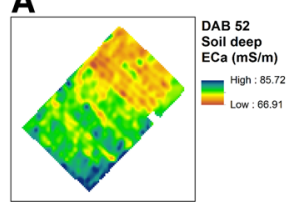

E
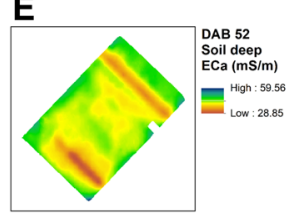

B

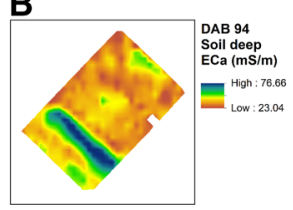

$F$
C

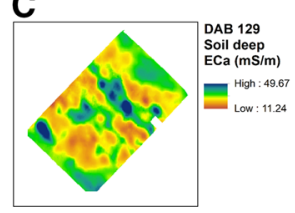

G

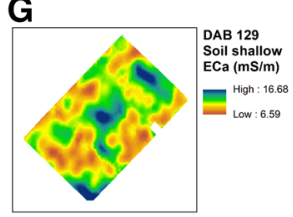

D

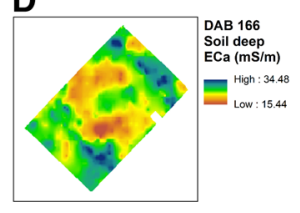

H

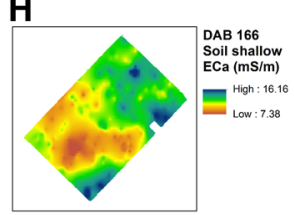

Fig. 4 Soil apparent electrical conductivity $\left(E_{a}\right)$ sensing by EM38 throughout the growing season in 2019. a DAB 52 deep $\mathrm{EC}_{\mathrm{a}}$, b DAB 94 deep $\mathrm{EC}_{\mathrm{a}}$, c DAB 129 deep $\mathrm{EC}_{\mathrm{a}}$, d DAB 166 deep $\mathrm{EC}_{\mathrm{a}}$, e DAB 52 shallow $\mathrm{EC}_{\mathrm{a}}$, f DAB 94 shallow $\mathrm{EC}_{\mathrm{a}}$, g DAB 129 shallow $\mathrm{EC}_{\mathrm{a}}$, $\mathbf{h} \mathrm{DAB} 166$ shallow $\mathrm{EC}_{\mathrm{a}} . \mathrm{DAB}$ days after bud-break (Fig. 4d and $4 \mathrm{~h}$ previously appeared in Yu and Kurtural 2020) (Color figure online) 
northeastern section of the vineyard showed lower $\mathrm{EC}_{\mathrm{a}}$ values (Fig. $4 \mathrm{a}$ ). The same spatial pattern was evident at $94 \mathrm{DAB}$, although there was a smaller portion in the southeastern section of vineyard having relatively higher $\mathrm{EC}_{\mathrm{a}}$ (Fig. 4b). At $129 \mathrm{DAB}$, the spatial pattern observed previously became not evident (Fig. 4c) and at $166 \mathrm{DAB}$, when harvest started, the central section showed lower $\mathrm{EC}_{\mathrm{a}}$ relative to the rest of the vineyard (Fig. $4 \mathrm{~d}$ ).

In the shallow soil layer, a small portion of the southwestern section and the northeastern section of the vineyard had lower $\mathrm{EC}_{\mathrm{a}}$ values (Fig. 4e). The smaller portion in the northeastern section appeared to be confined within one or two vineyard rows. However, the irrigation was not applied to the vineyard before $63 \mathrm{DAB}$. Thus, the spatial pattern was derived exclusively from the soil conditions prior to the occurrence of the first irrigation. At $94 \mathrm{DAB}$, lower $\mathrm{EC}_{\mathrm{a}}$ values kept occurring southwestern section of the vineyard (Fig. 4f). And similar to what was observed in deep soil, the spatial pattern at 94 DAB became unclear on 129 DAB (Fig. 4g). On the 166 DAB, which corresponded with the harvest date, relatively lower $\mathrm{EC}_{\mathrm{a}}$ values were measured in the northwestern section of the vineyard compared to the rest of the vineyard (Fig. $4 \mathrm{~h}$ ).

\section{Relationship between soil $\mathrm{EC}_{\mathrm{a}}$ and soil properties}

Previous studies have observed a positive correlation between soil water content and soil $\mathrm{EC}_{\mathrm{a}}$ (or negative correlation with soil $\mathrm{ER}_{\mathrm{a}}$ ) (Brillante et al. 2014). This was possibly among the reasons why the $\mathrm{EC}_{\mathrm{a}}$ values kept decreasing throughout the season at the study vineyard due to the progressive soil moisture depletion during the course of the hot and dry summer. Also, since the soil $\mathrm{EC}_{\mathrm{a}}$ is an integrated variable reflecting many individual soil characteristics, some previous research works indicated that other soil parameters can be used to predict its values (E. A. Costantini et al. 2010; Rodríguez-Pérez et al. 2011; Peralta and Costa 2013). A multivariate regression analysis was performed and a model was fitted with six soil variables, including soil organic carbon, gravel content, silt, clay, $\mathrm{EC}_{\mathrm{e}}$, and water content, to the soil EC $\mathrm{E}_{\mathrm{a}}$ assessed with EMI (Table 2). Such model could provide a prediction of $\mathrm{EC}_{\mathrm{a}}$ with $\mathrm{R}^{2}=0.96$ and $p=1.288 \mathrm{e}-13$, degree of freedom $=21$. The equation of the multivariate regression model is:

$$
\mathrm{EC}_{\mathrm{a}}=8.669+1.844 \mathrm{SOC}+1.363 \mathrm{GR}+1.384 \mathrm{~S}+0.762 \mathrm{EC}_{\mathrm{e}}-0.699 \mathrm{C}+0.127 \mathrm{SWC}
$$

Table 2 Multivariate regression analysis of soil electrical conductivity based on soil predictors

\begin{tabular}{lrrrl}
\hline & Estimate & Std. Error & t value & $\operatorname{Pr}(>|\mathrm{t}|)$ \\
\hline (Intercept) & 8.669 & 3.784 & 2.291 & $0.032^{*}$ \\
SOC & 1.844 & 10.387 & 0.178 & 0.861 \\
GRAVEL & 1.363 & 0.438 & 3.111 & $0.005^{* *}$ \\
SILT & 1.384 & 0.503 & 2.750 & $0.012^{*}$ \\
EC & 0.762 & 6.315 & 0.121 & 0.905 \\
CLAY & -0.699 & 0.378 & -1.850 & 0.078 \\
WATER & 0.127 & 0.050 & 2.545 & $0.019^{*}$
\end{tabular}

Residual standard error: 3.79 on 21 degrees of freedom

Multiple r-squared: 0.9603, Adjusted r-squared: 0.949

F-statistic: 84.7 on 6 and $21 \mathrm{DF}, p$-value: $1.288 \mathrm{e}-13$

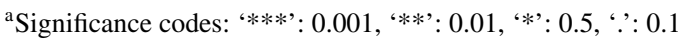


where SOC is soil organic carbon (converted from $\%$ to $\mathrm{g}$ ), GR is gravel (converted from $\%$ to $\mathrm{g}$ ), $\mathrm{S}$ silt (converted from $\%$ to $\mathrm{g}$ ), $\mathrm{EC}_{\mathrm{e}}$ is soil pore water electrical conductivity $\left(\mathrm{mS} \mathrm{m}^{-1}\right), \mathrm{C}$ is clay (converted from $\%$ to $\mathrm{g}$ ), and SWC is soil water content (converted from vol $\%$ in volume to $\mathrm{mm}$ ). These soil variables were considered in this model since they are relatively stable in the vineyard soils and there was no need for recurring (or periodic) measurements except $\mathrm{EC}_{\mathrm{e}}$, and soil water content. Thus, this model worked well when transferring soil water content to soil $\mathrm{EC}_{\mathrm{a}}$. When regressing the values of $\mathrm{EC}_{\mathrm{a}}$ estimated with this model and the $\mathrm{EC}_{\mathrm{a}}$ values observed in the field from EM38 readings, an $\mathrm{r}^{2}$ of $0.5770, p$ value of 0.0002 , and root mean square error (RMSE) of $4.8349 \mathrm{mS} \mathrm{m}^{-1}$ were obtained (Fig. 5). When the analysis of relative importance was conducted, it was found that soil water content contributed the most and significantly to soil $\mathrm{EC}_{\mathrm{a}}$, at $24 \%$ (Fig. 6). Soil texture was the second contributor to soil $\mathrm{EC}_{\mathrm{a}}$, including silt with $22.4 \%$ and clay with $18.2 \%$ relative contributions, respectively. The soil-water $\mathrm{EC}_{\mathrm{e}}$ had the least contribution towards soil $\mathrm{EC}_{\mathrm{a}}$ among these six predictors with $5.5 \%$. Some previous studies have shown that $\mathrm{EC}_{\mathrm{e}}$ might be a direct soil property affecting soil $\mathrm{EC}_{\mathrm{a}}$, hence it can be assessed proximally (Corwin and Lesch 2013). This seemed not to be the case in this study due to the low soil-water $\mathrm{EC}_{\mathrm{e}}$ at the study site in Napa County, California (Weber et al. 2014). However, when $\mathrm{EC}_{\mathrm{e}}$ is more pronounced in the vineyard soils, there would be the need to adjust the model, as salinity may very likely have greater influence on soil $\mathrm{EC}_{\mathrm{a}}(\mathrm{E}$. A. Costantini et al. 2010). It was noted that specific soil physical conditions should be properly considered when relating soil water content to $\mathrm{EC}_{\mathrm{a}}$ (Morari et al. 2009). In this study, results provided

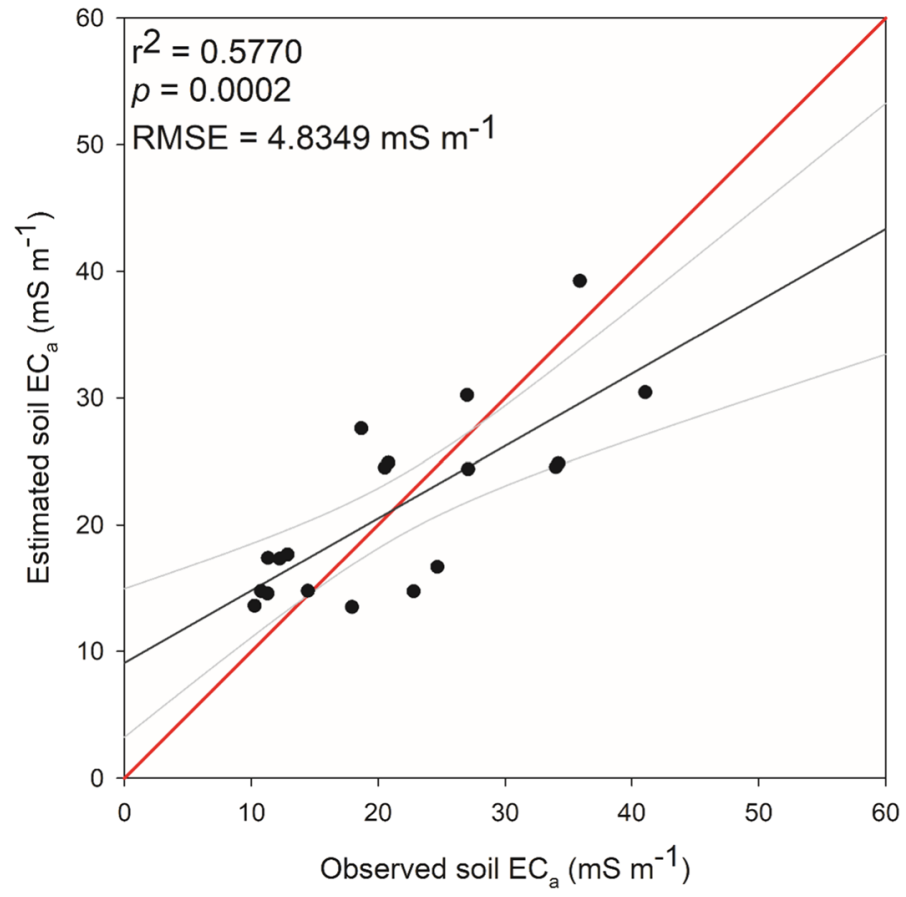

Fig. 5 Predicted and observed values for the multivariate model with soil apparent electrical conductivity $\left(\mathrm{EC}_{\mathrm{a}}\right)$ from the soil predictors. Grey lines indicate $95 \%$ confidence interval, red line indicates the line with a slope of 1 and an intercept of 0 (Color figure online) 
Fig. 6 Relative importance analysis of each predictor for the multivariate model deriving soil apparent electrical conductivity $\left(\mathrm{EC}_{\mathrm{a}}\right.$ ) by soil physical-chemical properties as predictors, including soil water content, silt, clay, SOC (soil organic carbon), gravel, and soil pore water electrical conductivity $\left(\mathrm{EC}_{\mathrm{e}}\right)$

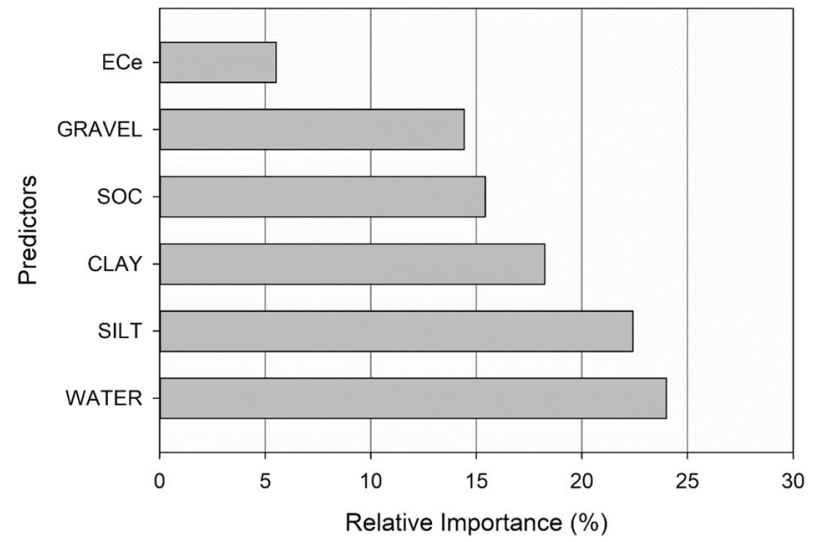

evidence that the soil texture acted as the main soil variable on soil $\mathrm{EC}_{\mathrm{a}}$, as it has strong influence on the soil moisture content. The proposed multivariate approach allowed taking into consideration various soil properties that are both spatially and temporally variable. The measurement of these parameters may be labor intensive and time consuming, and thus difficult to conduct during the dry and hot summers typically occurring in the study region. Given that the soil texture is stable over time, once the soil texture is determined, then the spatially-distributed plant water status could be easily inferred from the soil $\mathrm{EC}_{\mathrm{a}}$ with periodic EMI surveys. Furthermore, some physiological responses of the plant that are water-related may also be assessed and interpreted from soil $\mathrm{EC}_{\mathrm{a}}$.

\section{Relationship between soil $\mathrm{EC}_{\mathrm{a}}$ and plant water status}

The spatial interpolation for LAI and NDVI were performed, and the spatial homogeneity for these parameters was also tested (Fig. 7). The CI value for LAI was more than 75 with $c_{0}$ of 1.017 and $c_{0}+c_{1}$ close to 0 ; the CI value for NDVI was 90.48 , which was also more than 75 . Since the grapevine LAI and NDVI did not show spatial dependency, the plant water status can be assumed derived directly from soil. Linear relationships were investigated between $\mathrm{EC}_{\mathrm{a}}$ and plant water status expressed in terms of $\Psi_{\text {stem }}$

A

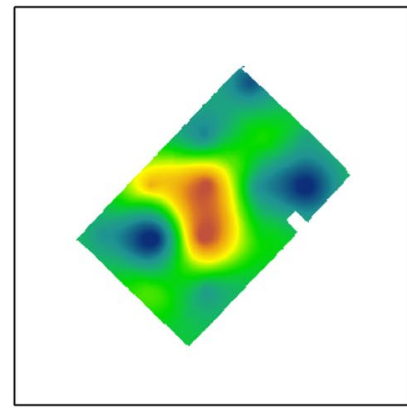

B

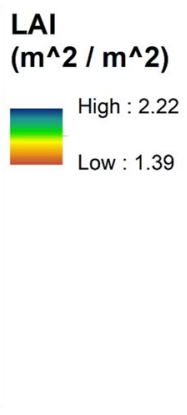

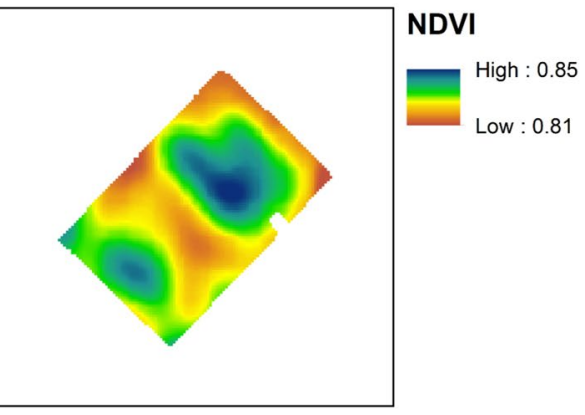

Fig. 7 Canopy assessments in a Cabernet Sauvignon (V. vinifera L.) vineyard in Oakville, California, USA. a Leaf area index (LAI), b normalized difference vegetation index (NDVI) (Color figure online) 
and $g_{\mathrm{s}}$ to evaluate the existence of direct relationships (Fig. 8). It was noticed that deep soil $\mathrm{EC}_{\mathrm{a}}$ was closely related to $\Psi_{\text {stem }}$ with an $\mathrm{r}^{2}$ of $0.7214, p$ value of 0.0038 , and RMSE of $0.1694 \mathrm{MPa}$ (Fig. 8a). However, the same relationship was not evident for the shallow soil layer (Fig. 8b). A similarly close relationship was observed between deep soil $\mathrm{EC}_{\mathrm{a}}$ and $g_{\mathrm{s}}$ with an $\mathrm{r}^{2}$ of $0.5007, p$ value of 0.0221 , and RMSE of $56.5192 \mathrm{mmol} \mathrm{H}_{2} \mathrm{O} \mathrm{m}^{-2} \mathrm{~s}^{-1}$. The higher the soil $\mathrm{EC}_{\mathrm{a}}$ became, the greater stomatal conductance was measured for the leaves (Fig. 8c). However, the relationship between $\mathrm{EC}_{\mathrm{a}}$ and $g_{\mathrm{s}}$ was not as close for the shallow soil layer (Fig. 8d). The $\Psi_{\text {stem }}$ and $g_{\mathrm{s}}$ were the two factors that very well reflected the plant water status, and they were also interrelated. In the case of the study vineyard, the seasonlong $\Psi_{\text {stem }}$ and $g_{\mathrm{s}}$ integrals were regressed and indicated an $\mathrm{r}^{2}$ of $0.6559, p$ value of 0.0004 , and RMSE of $20.9512 \mathrm{mmol} \mathrm{H}_{2} \mathrm{O} \mathrm{m}^{-2} \mathrm{~s}^{-1}$ (Fig. 9). A conceptual model developed within an earlier study on wheat indicated that the shallow soil was likely to increase the level of root-sourced signals due to most roots distributed within or close to top soil (Whalley et al. 2008). In the study vineyard, the soil $\mathrm{EC}_{\mathrm{a}}$ measured for the soil depth between 0 and $1.5 \mathrm{~m}$ showed strong and positive correlations with $\Psi_{\text {stem }}$ and $g_{\mathrm{s}}$, which was explained with the fact that most of the active roots were likely distributed within the top $0-1.5 \mathrm{~m}$ depth of the soil root zone.

Several other studies have evaluated the relations between the soil $\mathrm{EC}_{\mathrm{a}}\left(\right.$ or $\mathrm{ER}_{\mathrm{a}}$ ) and soil properties, which can help explaining plant water availability (Morari et al. 2009; Rodríguez-Pérez et al. 2011; Brillante et al. 2015). Similar relationships were observed in this study as those reported by previously. However, with the ability to measure two soil depths,
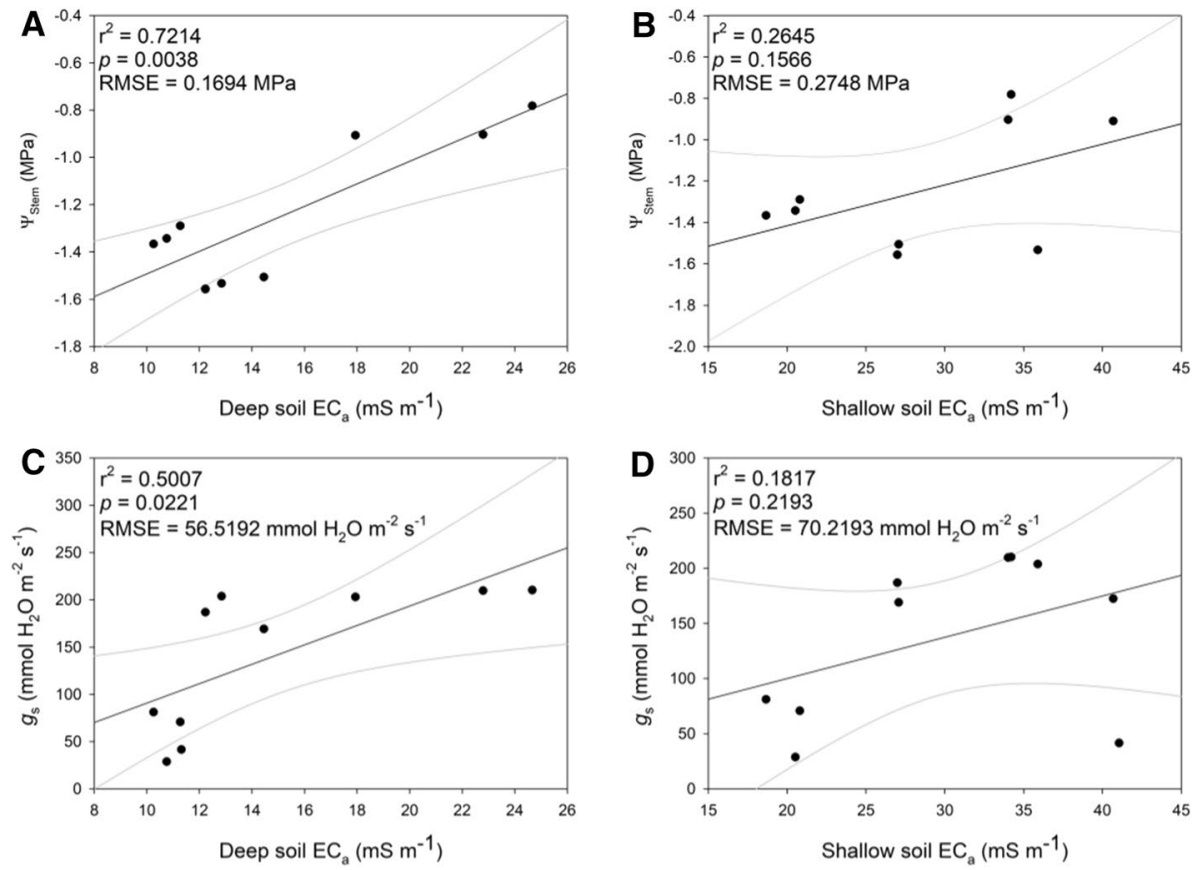

Fig. 8 Correlation between soil apparent electrical conductivity $\left(\mathrm{EC}_{\mathrm{a}}\right)$ assessed by EM38, corrected to a reference temperature of $25^{\circ} \mathrm{C}$ by time domain reflectometer (TDR) sensors, and stem water potential ( $\left.\Psi_{\text {stem }}\right)$ and leaf stomatal conductance $\left(g_{\mathrm{s}}\right)$ for 2019. a $\Psi_{\text {stem }}$ and deep soil EC $\mathrm{E}_{\mathrm{a}}$, b $\Psi_{\text {stem }}$ and shallow soil $\mathrm{EC}_{\mathrm{a}}$, c $g_{\mathrm{s}}$ and deep soil $\mathrm{EC}_{\mathrm{a}}, \mathbf{d} g_{\mathrm{s}}$ and shallow $\mathrm{EC}_{\mathrm{a}}$ 
Fig. 9 Relationships between stem water potential $\left(\Psi_{\text {stem }}\right)$ integrals and stomatal conductance $\left(g_{\mathrm{s}}\right)$ integrals in 2019

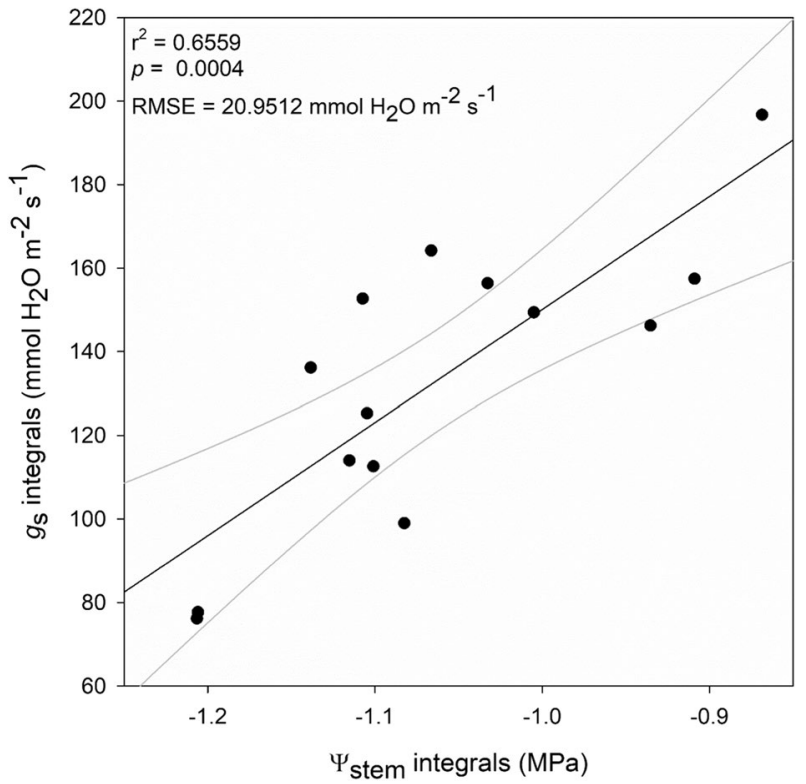

these relationships can be elucidated with more accuracy. Most of the previous studies have applied soil $\mathrm{EC}_{\mathrm{a}}$ sensing to test its applicability in delineating management zones in commercial orchards and vineyards (Brevik et al. 2006; Bramley et al. 2011a, 2011b), but without exploring the linkages between $\mathrm{EC}_{\mathrm{a}}$ and plant physiology. Previous works have shown that the soil $\mathrm{EC}_{\mathrm{a}}$ (or $\mathrm{ER}_{\mathrm{a}}$ ) assessed with proximal sensing had a positive relationship (or negative with $\mathrm{ER}_{\mathrm{a}}$ ) with grapevine trunk circumference (Trought et al. 2008; Rossi et al. 2013). Similar positive relationships were also reported between soil $\mathrm{EC}_{\mathrm{a}}$ and grapevine pruning mass determined with active canopy reflectance sensors (Bramley et al. 2011b) and with vegetation indices (Zarrouk et al. 2012). However, those studies did not investigate the relationship between soil $\mathrm{EC}_{\mathrm{a}}$ and plant water status. Having positive correlation with deep soil $\mathrm{EC}_{\mathrm{a}}$, NDVI also showed positive correlations with the applied water amount. Findings from these studies indicated that soil $\mathrm{EC}_{\mathrm{a}}$ could positively relate to the grapevine vegetative growth, which can vary across the field depending on access to water and nutrients and their uptake by plants, which in turn could be reflected in plant water status. Results presented herein provided evidence that soil $\mathrm{EC}_{\mathrm{a}}$ could provide relevant information of both grapevine vegetative growth and reproductive growth, including berry maturity in both primary and secondary metabolism (Bonfante et al. 2015; Yu et al. 2020), which can be used for water and nutrient management purposes. The study described in the present article provided evidence of the functional relationship between soil ECa and grapevine water uptake that could possibly be used to predict soil-plant water dynamics in commercial vineyards.

\section{Relationship of $\delta^{13} \mathrm{C}$ with stem water potential and leaf photosynthesis}

The must $\delta^{13} \mathrm{C}$ was closely and significantly correlated with plant water status, including season-long cumulative $\Psi_{\text {stem }}$ integrals (Fig. 10a) with $\mathrm{r}^{2}=0.9127, p$ value $<0.0001$, and $\mathrm{RMSE}=0.0316 \mathrm{MPa}$, and also with $g_{\mathrm{s}}$ integrals (Fig. 10b) with $\mathrm{r}^{2}=0.6985, p$ 

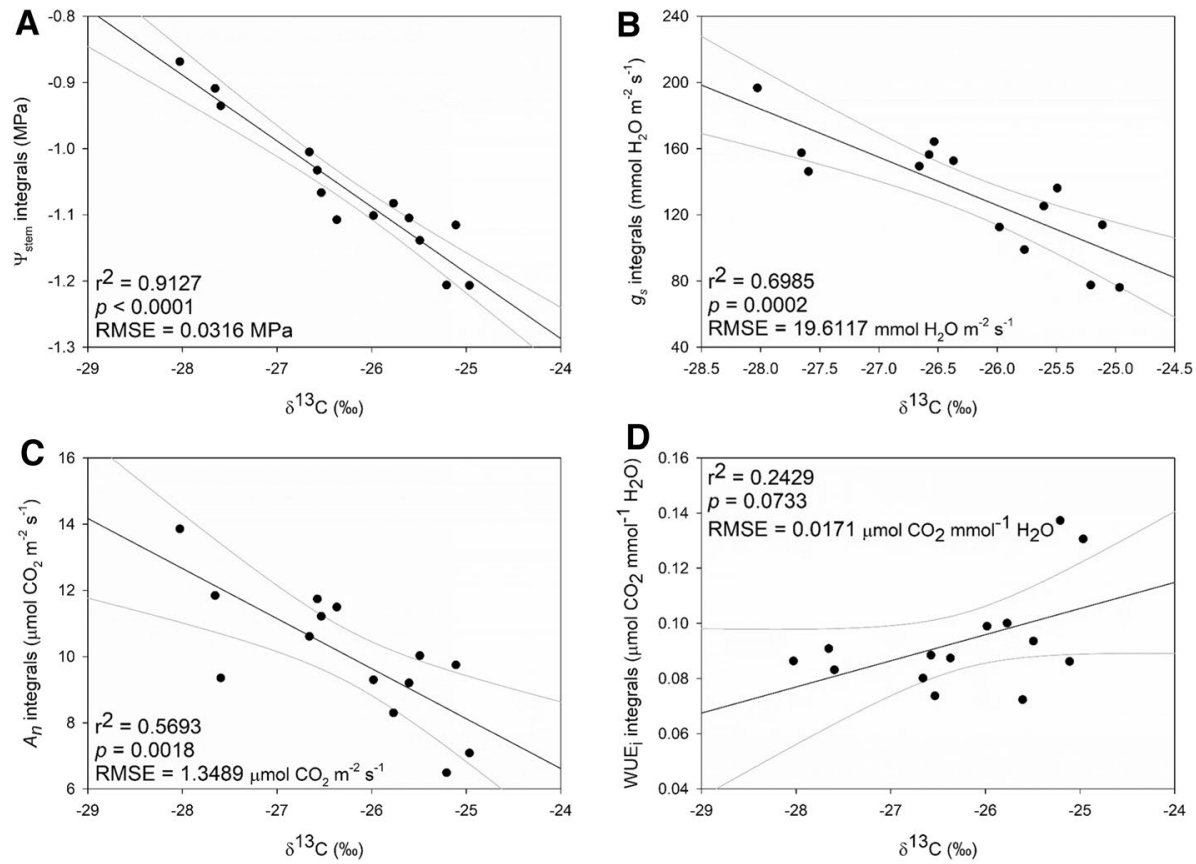

Fig. 10 Relationships between carbon isotope ratio analysis $\left(\delta^{13} \mathrm{C}\right)$ with season-long stem water potential and leaf gas exchange measurements. a Stem water potential integrals, $\Psi_{\text {stem }}$, b stomatal conductance integrals, $g_{\mathrm{s}}$, c net carbon assimilation integrals, $A_{n}$, $\mathbf{d}$ intrinsic water use efficiency integrals, WUE $\mathrm{H}_{\mathrm{i}}$

value $=0.0002$, and $\mathrm{RMSE}=19.6117 \mathrm{mmol} \mathrm{H}_{2} \mathrm{O} \mathrm{m}^{-2} \mathrm{~s}^{-1}$, and also with $A_{\mathrm{n}}$ (Fig. 10c) with $\mathrm{r}^{2}=0.5693, p$ value $=0.0018$, and $\mathrm{RMSE}=1.3489 \mu \mathrm{mol} \mathrm{CO} \mathrm{CO}^{-2} \mathrm{~s}^{-1}$. The relationship between $\delta^{13} \mathrm{C}$ and WUEi was not significant (Fig. 10d). Two earlier studies have already shown that $\delta^{13} \mathrm{C}$ may provide reliable predictions of plant water status as ancillary information for managing spatial variability (Martínez-Vergara et al. 2014; Brillante et al. 2016). Results from previous works indicated that soil characteristics and topography may influence $\delta^{13} \mathrm{C}$ based on modifications in the water continuum between soil and plants (Brillante et al. 2018). When $\delta^{13} \mathrm{C}$ to soil $\mathrm{EC}_{\mathrm{a}}$ were regressed in the current study, the relationships were not significant $(p>0.05)$, with $r^{2}=0.0015$ with deep soil $E_{a}$ and $r^{2}=0.1331$ with shallow soil $\mathrm{EC}_{\mathrm{a}}$ (Fig. 11). This was also observed in a previous study where the correlation between $\delta^{13} \mathrm{C}$ and soil $\mathrm{EC}_{\mathrm{a}}$ was not significant within the same vineyard (E. A. Costantini et al. 2010). According to previous research, $\delta^{13} \mathrm{C}$ showed close relations with stomatal conductance, with $\delta^{13} \mathrm{C}$ values increasing with water deficits. Hence, $\delta^{13} \mathrm{C}$ can relate to net carbon assimilation rate as well (Farquhar et al. 1989; Brillante et al. 2018). One study showed that low nitrogen availability overruled the dominant effect of plant water status on $\delta^{13} \mathrm{C}(\mathrm{E}$. A. C. Costantini et al. 2013), so the relationship between plant water status and $\delta^{13} \mathrm{C}$ could be lost if the photosynthesis was severely impaired due to shortage of nutrient deficits. Bchir et al. (Bchir et al. 2016) showed that $\delta^{13} \mathrm{C}$ and plant water status were correlated in young and mature leaves as well as berries. Results of this work provided additional evidence of the relationship of $\delta^{13} \mathrm{C}$ with plant water status, including midday $\Psi_{\text {stem }}$ and leaf photosynthesis during the berry maturation. Previous studies on $\delta^{13} \mathrm{C}$ were conducted in regions with relatively cool climate and rain-fed production systems (Bchir et al. 2016; Brillante et al. 

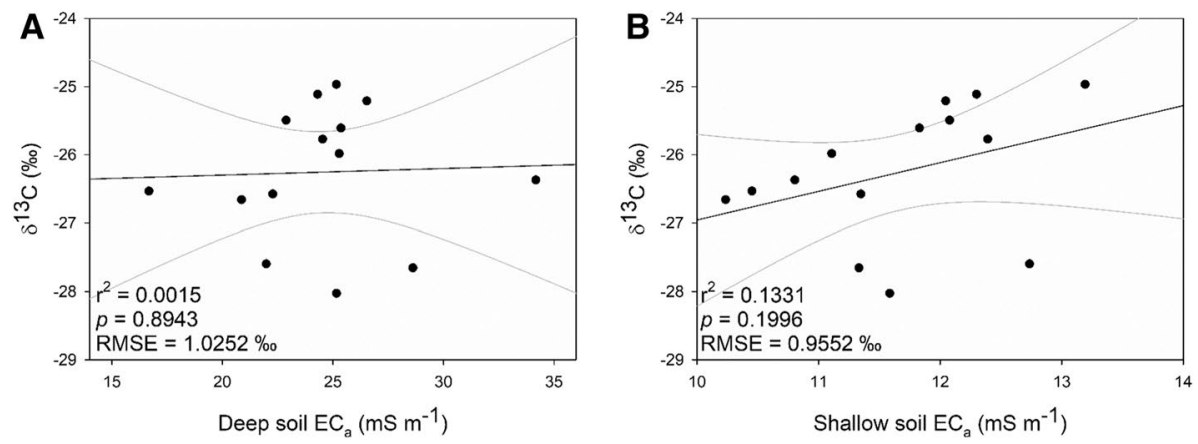

Fig. 11 Correlation between soil apparent electrical conductivity $\left(\mathrm{EC}_{\mathrm{a}}\right)$ assessed by EMI, and carbon isotope ratio analysis $\left(\delta^{13} \mathrm{C}\right)$. a Deep soil $\mathrm{EC}_{\mathrm{a}}$, b shallow soil $\mathrm{EC}_{\mathrm{a}}$

2018). The present study can be fundamental for a region-wide calibration, being the first providing evidence that $\delta^{13} \mathrm{C}$ relates to plant water status and leaf photosynthesis in hot and dry region as California where the majority of grapevine is grown with micro irrigation.

\section{Conclusion}

Results presented here-in revealed the spatial variability of soil features across the studied vineyard. Soil $\mathrm{EC}_{\mathrm{a}}$ measured with proximal sensing in the deep soil layer can be related to grapevine water status. The main hypothesis of this study was confirmed that the soil water content and soil texture were the main factors influencing soil $\mathrm{EC}_{\mathrm{a}}$ in this study, which would further determine plant water status. Hence, once the vineyard soil is surveyed and its texture determined, the soil $\mathrm{EC}_{\mathrm{a}}$ can be used to infer spatial variations in plant water status. Additionally, the results provided evidence that $\delta^{13} \mathrm{C}$ analysis on berry sugar can potentially be used to back-track the spatial variability in plant water status and photosynthesis during berry maturation. These results provide relevant and applicable information to support the use of proximal soil sensing for monitoring soil-plant-water dynamics and changes in commercial production vineyards. Such information may help designing and implementing management strategies that minimize or manage the spatial variability of grapevine productivity and wine grape quality in micro irrigated commercial production vineyards.

Acknowledgements The authors acknowledge the financial support provided to R. Yu by the department of Viticulture and Enology at UC Davis, Horticulture and Agronomy Graduate Group at UC Davis, and American Society of Enology and Viticulture.

\section{Compliance with ethical standards}

Conflict of interest The authors declare that the research was conducted in the absence of any commercial or financial relationships that could be construed as a potential conflict of interest.

Open Access This article is licensed under a Creative Commons Attribution 4.0 International License, which permits use, sharing, adaptation, distribution and reproduction in any medium or format, as long as you give appropriate credit to the original author(s) and the source, provide a link to the Creative Commons licence, and indicate if changes were made. The images or other third party material in this article are included in the article's Creative Commons licence, unless indicated otherwise in a credit line to the 
material. If material is not included in the article's Creative Commons licence and your intended use is not permitted by statutory regulation or exceeds the permitted use, you will need to obtain permission directly from the copyright holder. To view a copy of this licence, visit http://creativecommons.org/licenses/by/4.0/.

\section{References}

Acevedo-Opazo, C., Ortega-Farias, S., \& Fuentes, S. (2010). Effects of grapevine (Vitis vinifera L.) water status on water consumption, vegetative growth and grape quality: An irrigation scheduling application to achieve regulated deficit irrigation. Agricultural Water Management, 97, 956-964. https://doi. org/10.1016/j.agwat.2010.01.025.

André, F., van Leeuwen, C., Saussez, S., van Durmen, R., Bogaert, P., Moghadas, D., et al. (2012). Highresolution imaging of a vineyard in south of France using ground-penetrating radar, electromagnetic induction and electrical resistivity tomography. Journal of Applied Geophysics, 78, 113-122. https:// doi.org/10.1016/j.jappgeo.2011.08.002.

Bchir, A., Escalona, J. M., Gallé, A., Hernández-Montes, E., Tortosa, I., Braham, M., \& Medrano, H. (2016). Carbon isotope discrimination $\left(\delta^{13} \mathrm{C}\right)$ as an indicator of vine water status and water use efficiency (WUE): Looking for the most representative sample and sampling time. Agricultural water management, 167, 11-20. https://doi.org/10.1016/j.agwat.2015.12.018.

Bittelli, M. (2011). Measuring soil water content: A review. HortTechnology, 21, 293-300. https://doi. org/10.21273/HORTTECH.21.3.293.

Bonfante, A., Agrillo, A., Albrizio, R., Basile, A., Buonomo, R., de Mascellis, R., et al. (2015). Functional homogeneous zones (fHZs) in viticultural zoning procedure: an Italian case study on Aglianico vine. Soil, 1, 427-441. https://doi.org/10.5194/soil-1-427-2015.

Bramley, R., Ouzman, J., \& Boss, P. (2011a). Variation in vine vigour, grape yield and vineyard soils and topography as indicators of variation in the chemical composition of grapes, wine and wine sensory attributes. Australian Journal of Grape and Wine Research, 17, 217-229. https://doi.org/10.111 1/j.1755-0238.2011.00136.x.

Bramley, R., Trought, M. C., \& Praat, J. P. (2011b). Vineyard variability in Marlborough, New Zealand: characterising variation in vineyard performance and options for the implementation of Precision Viticulture. Australian Journal of Grape and Wine Research, 17, 72-78. https://doi.org/10.111 1/j.1755-0238.2010.00119.x.

Brevik, E. C., Fenton, T. E., \& Lazari, A. (2006). Soil electrical conductivity as a function of soil water content and implications for soil mapping. Precision Agriculture, 7, 393-404. https://doi.org/10.1007/ s11119-006-9021-x.

Brillante, L., Bois, B., Mathieu, O., Bichet, V., Michot, D., \& Lévêque, J. (2014). Monitoring soil volume wetness in heterogeneous soils by electrical resistivity. A field-based pedotransfer function. Journal of hydrology, 516, 56-66. https://doi.org/10.1016/j.jhydrol.2014.01.052.

Brillante, L., Mathieu, O., Bois, B., van Leeuwen, C., \& Lévêque, J. (2015). The use of soil electrical resistivity to monitor plant and soil water relationships in vineyards. Soil, 1, 273-286. https://doi. org/10.5194/soil-1-273-2015.

Brillante, L., Mathieu, O., Lévêque, J., \& Bois, B. (2016). Ecophysiological modeling of grapevine water stress in burgundy terroirs by a machine-learning approach. Frontiers in plant science, 7, 796. https:// doi.org/10.3389/fpls.2016.00796.

Brillante, L., Mathieu, O., Lévêque, J., van Leeuwen, C., \& Bois, B. (2018). Water status and must composition in grapevine cv. Chardonnay with different soils and topography and a mini meta-analysis of the $\delta 13 \mathrm{C} /$ water potentials correlation. Journal of the Science of Food and Agriculture, 98, 691-697. https ://doi.org/10.1002/jsfa.8516.

Cambardella, C. A., Moorman, T. B., Novak, J., Parkin, T., Karlen, D., Turco, R., \& Konopka, A. (1994). Field-scale variability of soil properties in central Iowa soils. Soil science society of America journal, 58, 1501-1511. https://doi.org/10.2136/sssaj1994.03615995005800050033x.

Coombe, B. (1995). Grapevine growth stages-The modified EL system. Australian Journal of Grape and Wine Research, 1, 100-110. https://doi.org/10.1111/j.1755-0238.1995.tb00086.x.

Corwin, D. L., \& Lesch, S. M. (2013). Protocols and guidelines for field-scale measurement of soil salinity distribution with ECa-directed soil sampling. Journal of Environmental and Engineering Geophysics, 18, 1-25. https://doi.org/10.2113/JEEG18.1.1.

Costantini, E. A. C., Agnelli, A., Bucelli, P., Ciambotti, A., Dell'Oro, V., Natarelli, L., et al. (2013). Unexpected relationships between $\delta 13 \mathrm{C}$ and wine grape performance in organic farming. OENO One, 47, 269-285. https://doi.org/10.20870/oeno-one.2013.47.4.1556. 
Costantini, E. A., Pellegrini, S., Bucelli, P., Barbetti, R., Campagnolo, S., Storchi, P., et al. (2010). Mapping suitability for Sangiovese wine by means of $\delta 13 \mathrm{C}$ and geophysical sensors in soils with moderate salinity. European Journal of Agronomy, 33, 208-217. https://doi.org/10.1016/j.eja.2010.05.007.

Dai, Z. W., Léon, C., Feil, R., Lunn, J. E., Delrot, S., \& Gomès, E. (2013). Metabolic profiling reveals coordinated switches in primary carbohydrate metabolism in grape berry (Vitis vinifera L.), a non-climacteric fleshy fruit. Journal of Experimental Botany, 64, 1345-1355. https://doi.org/10.1093/jxb/ers396.

de Bei, R., Fuentes, S., Gilliham, M., Tyerman, S., Edwards, E., Bianchini, N., et al. (2016). VitiCanopy: A free computer App to estimate canopy vigor and porosity for grapevine. Sensors, 16, 585. https:// doi.org/10.3390/s16040585.

De Clercq, W., Van Meirvenne, M., \& Fey, M. (2009). Prediction of the soil-depth salinity-trend in a vineyard after sustained irrigation with saline water. Agricultural water management, 96, 395-404. https://doi.org/10.1016/j.agwat.2008.09.002.

Farquhar, G. D., Ehleringer, J. R., \& Hubick, K. T. (1989). Carbon isotope discrimination and photosynthesis. Annual review of plant biology, 40, 503-537. https://doi.org/10.1146/annurev.pp.40.06018 9.002443 .

Farquhar, G. D., O’Leary, M. H., \& Berry, J. A. (1982). On the relationship between carbon isotope discrimination and the intercellular carbon dioxide concentration in leaves. Functional Plant Biology, 9, 121-137. https://doi.org/10.1071/PP9820121.

Gaudillère, J. P., van Leeuwen, C., \& Ollat, N. (2002). Carbon isotope composition of sugars in grapevine, an integrated indicator of vineyard water status. Journal of experimental Botany, 53, 757763. https://doi.org/10.1093/jexbot/53.369.757.

Grömping, U. (2006). Relative Importance for Linear Regression in R: The Package relaimpo. Journal of Statistical Software, 17(1), 1-27. https://doi.org/10.18637/jss.v017.i01.

Hayashi, M. (2004). Temperature-electrical conductivity relation of water for environmental monitoring and geophysical data inversion. Environmental monitoring and assessment, 96, 119-128. https:// doi.org/10.1023/B:EMAS.0000031719.83065.68.

Hedley, C., Yule, I., Eastwood, C., Shepherd, T., \& Arnold, G. (2004). Rapid identification of soil textural and management zones using electromagnetic induction sensing of soils. Soil Research, 42, 389-400. https://doi.org/10.1071/SR03149.

Kriegler, F., Malila, W., Nalepka, R. \& Richardson, W. Preprocessing transformations and their effects on multispectral recognition. Remote sensing of environment, VI, 1969. 97

Martínez-Vergara, A., Payan, J.-C., Salançon, E., \& Tisseyre, B. (2014). Spiderס: an empirical method to extrapolate grapevine (Vitis vinifera L.) water status at the whole denomination scale using $\delta^{13} \mathrm{C}$ as ancillary data. OENO One, 48, 129-140. https://doi.org/10.20870/oeno-one.2014.48.2.1569.

Morari, F., Castrignanò, A., \& Pagliarin, C. (2009). Application of multivariate geostatistics in delineating management zones within a gravelly vineyard using geo-electrical sensors. Computers and Electronics in Agriculture, 68, 97-107. https://doi.org/10.1016/j.compag.2009.05.003.

Ojeda, H., Deloire, A., \& Carbonneau, A. (2001). Influence of water deficits on grape berry growth. Vitis-Geilweilerhof, 40, 141-146. https://doi.org/10.5073/vitis.2001.40.141-145.

Peel, M. C., Finlayson, B. L., \& McMahon, T. A. (2007). Updated world map of the Köppen-Geiger climate classification. Hydrology and Earth System Sciences. https://doi.org/10.5194/ hess-11-1633-2007.

Peralta, N. R., \& Costa, J. L. (2013). Delineation of management zones with soil apparent electrical conductivity to improve nutrient management. Computers and Electronics in Agriculture, 99, 218-226. https://doi.org/10.1016/j.compag.2013.09.014.

Rodríguez-Pérez, J. R., Plant, R. E., Lambert, J.-J., \& Smart, D. R. (2011). Using apparent soil electrical conductivity $\left(\mathrm{EC}_{\mathrm{a}}\right)$ to characterize vineyard soils of high clay content. Precision Agriculture, 12, 775-794. https://doi.org/10.1007/s11119-011-9220-y.

Rossi, R., Pollice, A., Diago, M.-P., Oliveira, M., Millan, B., Bitella, G., et al. (2013). Using an automatic resistivity profiler soil sensor on-the-go in precision viticulture. Sensors, 13, 1121-1136. https://doi.org/10.3390/s130101121.

Scholander, P. F., Bradstreet, E. D., Hemmingsen, E., \& Hammel, H. (1965). Sap pressure in vascular plants: negative hydrostatic pressure can be measured in plants. Science, 148, 339-346. https://doi. org/10.1126/science.148.3668.339.

Smart, D. R., Schwass, E., Lakso, A., \& Morano, L. (2006). Grapevine rooting patterns: a comprehensive analysis and a review. American Journal of Enology and Viticulture, 57, 89-104.

Soar, C. J., \& Loveys, B. (2007). The effect of changing patterns in soil-moisture availability on grapevine root distribution, and viticultural implications for converting full-cover irrigation into a pointsource irrigation system. Australian Journal of Grape and Wine Research, 13, 2-13. https://doi. org/10.1111/j.1755-0238.2007.tb00066.x. 
Steenwerth, K., Drenovsky, R., Lambert, J.-J., Kluepfel, D., Scow, K., \& Smart, D. (2008). Soil morphology, depth and grapevine root frequency influence microbial communities in a Pinot noir vineyard. Soil Biology and Biochemistry, 40, 1330-1340. https://doi.org/10.1016/j.soilbio.2007.04.031.

Tagarakis, A., Liakos, V., Fountas, S., Koundouras, S., \& Gemtos, T. (2013). Management zones delineation using fuzzy clustering techniques in grapevines. Precision Agriculture, 14, 18-39. https://doi. org/10.1007/s11119-012-9275-4.

Tramontini, S., van Leeuwen, C., Domec, J.-C., Destrac-Irvine, A., Basteau, C., Vitali, M., et al. (2013). Impact of soil texture and water availability on the hydraulic control of plant and grape-berry development. Plant and soil, 368, 215-230. https://doi.org/10.1007/s11104-012-1507-x.

Trought, M. C., Dixon, R., Mills, T., Greven, M., Agnew, R., Mauk, J. L., \& Praat, J.-P. (2008). The impact of differences in soil texture within a vineyard on vine vigour, vine earliness and juice composition. OENO One, 42, 67-72. https://doi.org/10.20870/oeno-one.2008.42.2.828.

Van Leeuwen, C., Pieri, P., \& Vivin, P. (2010). Comparison of Three Operational Tools for the Assessment of Vine Water water Status: Stem Water Potential stem water potential, Carbon Isotope Discrimination carbon isotope discrimination Measured on Grape Sugar and Water Balance. In S. Delrot, H. Medrano, E. Or, L. Bavaresco, \& S. Grando (Eds.), Methodologies and results in grapevine research. New York: Springer.

Weber, E., Grattan, S., Hanson, B., Vivaldi, G., Meyer, R., Prichard, T., \& Schwankl, L. (2014). Recycled water causes no salinity or toxicity issues in Napa vineyards. California Agriculture, 68, 59-67. https:// doi.org/10.3733/ca.v068n03p59.

Whalley, W. R., Watts, C. W., Gregory, A. S., Mooney, S. J., Clark, L. J., \& Whitmore, A. P. (2008). The effect of soil strength on the yield of wheat. Plant and Soil, 306, 237. https://doi.org/10.1007/s1110 4-008-9577-5.

Wickham, H., François, R., Henry, L. \& Müller, K. 2020. dplyr: A Grammar of Data Manipulation. R package version 0.8.4.

Williams, L., \& Araujo, F. (2002). Correlations among predawn leaf, midday leaf, and midday stem water potential and their correlations with other measures of soil and plant water status in Vitis vinifera. Journal of the American Society for Horticultural Science, 127, 448-454. https://doi.org/10.21273/ JASHS.127.3.448.

Williams, L., \& Ayars, J. (2005). Grapevine water use and the crop coefficient are linear functions of the shaded area measured beneath the canopy. Agricultural and Forest Meteorology, 132, 201-211. https:// doi.org/10.1016/j.agrformet.2005.07.010.

Winkler, A. J., Cook, J. A., Kliewer, W., \& Lider, L. A. (1974). General Viticulture. Oakland, California: Univ of California Press.

Yu, R., Brillante, L., Martinez, J., \& Kurtural, S. K. (2020). Spatial Variability of Soil and Plant Water Status and their Cascading Effects on Grapevine Physiology are linked to Berry and Wine Chemistry. Frontiers in Plant Science, 11, 790. https://doi.org/10.3389/fpls.2020.00790.

Yu, R., \& Kurtural, S. K. (2020). Proximal sensing of soil electrical conductivity provides a link to soilplant water relationships and supports the identification of plant water status zones in vineyards. Frontiers in Plant Science, 11, 244. https://doi.org/10.3389/fpls.2020.00244.

Zarrouk, O., Francisco, R., Pinto-Marijuan, M., Brossa, R., Santos, R. R., Pinheiro, C., et al. (2012). Impact of irrigation regime on berry development and flavonoids composition in Aragonez (Syn. Tempranillo) grapevine. Agricultural Water Management, 114, 18-29. https://doi.org/10.1016/j.agwat.2012.06.018.

Publisher's Note Springer Nature remains neutral with regard to jurisdictional claims in published maps and institutional affiliations.

\section{Authors and Affiliations}

\section{Runze Yu ${ }^{1} \mathbb{D} \cdot$ Daniele Zaccaria $^{2} \mathbb{D} \cdot$ Isaya Kisekka $^{2} \mathbb{D} \cdot$ S. Kaan Kurtural ${ }^{1} \mathbb{D}$}

1 Department of Viticulture and Enology, University of California Davis, One Shields Avenue, Davis, CA 95616, USA

2 Department of Land, Air and Water Resources, University of California Davis, One Shields Avenue, Davis, CA 95616, USA 